\title{
Islamic schooling, migrant Muslims and the problem of integration in The Netherlands
}

\section{Muslih Muslih}

To cite this article: Muslih Muslih (2019): Islamic schooling, migrant Muslims and the problem of integration in The Netherlands, British Journal of Religious Education, DOI: 10.1080/01416200.2019.1628004

To link to this article: https://doi.org/10.1080/01416200.2019.1628004

册 Published online: 09 Jun 2019.

Submit your article to this journal $\asymp$

Џll Article views: 220

Q View related articles $\asymp$

View Crossmark data $\nearrow$ 


\title{
Islamic schooling, migrant Muslims and the problem of integration in The Netherlands
}

\author{
Muslih Muslih \\ Faculty of Education and Teacher Training, Walisongo State Islamic University Semarang, Semarang, Indonesia
}

\begin{abstract}
In the Netherlands, Islamic schools and Islamic education in general have been subjects of public debate for quite some time. After the event of $9 /$ 11 , they found themselves increasingly being criticised and some people in Dutch society go as far as considering them breeding grounds for terrorism and think they foster an anti-integration attitude among their students. In this article, however, I will demonstrate that Islamic education can function in and be adjusted well to the requirements of the local communities where Islamic education is offered to Muslims. I will argue that in the Netherlands teachers utilise Islamic primary schools to promote their students' integration into Dutch society, as their mission statements indeed explicitly state. The inclusion of civic education into the curriculum of Islamic schools is another indication that they seriously teach their students how to be good citizens who can actively participate in Dutch society. This article is thus to show that Islamic primary schools are well able to prepare their students both physically and mentally for integration into Dutch society.
\end{abstract}

\section{KEYWORDS}

Islamic primary school; social integration; Muslims in

Dutch society

\section{Introduction}

Many researchers have studied Islamic primary schools and examined them from a variety of perspectives. Their studies offer a wealth of information about the dynamics of Islamic education with reference to Islamic primary schools in the Netherlands (See, e.g. Driessen and Bezemer 1999; Driessen and Merry 2006; Driessen and Valkenberg 2000; Dronkers 2016; Merry and Driessen 2005, 2016; Shadid and van Koningsveld 2006). After 9/11, part of Dutch society has become more weary of Islamic schools in the Netherlands because they are considered breeding grounds for terrorism. Some people (especially from populist groups) even call for the abolition of Islamic schools in this country altogether. Despite these attacks, Islamic schools - except for two schools that had to be closed down because they did not meet minimum quality standards - still exist today. The central questions in this article are: How do Islamic schools manage to survive in the Netherlands in the midst of ongoing political changes and what strategies the Muslim community uses to ensure these schools' survival? In other words, central in this article are the strategies these schools adopt in order to survive in the midst of the critical onslaught the Dutch public levels against them, how they adapt to political changes in the country, how they mobilise their internal structures, and how they frame themselves.

To answer these questions I will do the following. Firstly, I will present a brief review of the debates over Islamic schools in the Netherlands. Secondly, I will analyse the performance of Islamic schools in the Netherlands. Thirdly, I will examine the efforts Islamic primary schools make to promote social integration. 
Following Tarrow $(2011,9)$, who sees social movements not as expressions of extremism and violence but rather as 'collective challenges, based on common purposes and social solidarities, in sustained interaction with elites, opponents, and authorities', I think that the struggle of immigrant Muslims, as a minority, to establish Islamic educational institutions in the Netherlands might be considered a form of social movement in this sense. Indeed, the four elements in Tarrow's definition above (collective challenge, common purpose, social solidarity, and sustained interaction) play a role in the process of establishing Islamic school in this country, as we will see below.

\section{Debate on the desirability of Islamic schools}

Shadid and van Koningsveld $(2006,83-85)$ posit three periods in the development of Islamic schools in the Netherlands and how the Dutch public reacted against it. The first period (1988-1997) was a period in which the debate about Islamic schools in Dutch society focused mostly on its desirability. In the second period (1998-2000) discussions focused more on the quality of the education Islamic schools offered. The third period (2001-2005) saw the beginning of criticism against Islamic education in the West including the Netherlands. After the event of 11 September 2001, public opinion in the West started to relate the influence of political Islam with Islamic schools. Its impact was that many began questioning 'the integration of Muslim children into Dutch society'. Following Shadid and van Koningsveld's periodisation, in my observation, the condition from 2005 until today is more or less a continuation of their third period.

The Netherlands is one of the countries in Western Europe with a large number of Muslims. Today, the total population of the Netherlands is estimated to be more than 17.1 million and roughly five per cent (around 855 thousand) are Muslims (https://www.statista.com/; http://world populationreview.com/). According to the Dutch constitution the State guarantees the right of every citizen to have an education and every individual is free to practice his or her faith without any discrimination (Van Genugten 2013, 78). The Dutch constitutional 'freedom of education' offers religious and non-religious foundations the right 'to found schools within the state parameters of educational quality and supervision' (Dronkers 2016,6). Thus, like citizens of other denominations, Muslims are entitled to education based on their faith.

Aware of their rights, Muslim communities demanded the Dutch government to establish Islamic schools so that their children could have religious education to protect them from being corrupted by the un-Islamic values prevalent in secular Dutch society. It confirms what Tarrow termed 'collective challenges' (the first property in his definition of social movement), which views that characteristically it mounts 'contentious challenges through disruptive direct action against elites, authorities, other groups, or cultural codes' (Tarrow 2011, 10). The common purpose Muslim communities have in the Netherlands is to safeguard their religion and pass on their culture to their children to preserve their Muslim identity (Merry 2005, 379). In fact, as Hussain pointed out, what the Muslims in the Netherlands feel finds its theological justification in the fact that Islamic education for Muslims is just one element of the wider Islamic theology where primacy of science and autonomous human and secular reality are non-existent' (Hussain 2010, 236).

Social solidarity is another property of social movements as defined by Tarrow. The social solidarity among Muslims in the Netherlands (Moroccan and Turkish) derives from their shared feeling that they are immigrants in this country. Apart from their ethnic differences they brought from their native countries, they are united by the fact that they embrace the same religion namely Islam. It seems that Islam is the identity they want to guard and pass on to their children. They want to be Dutch citizens but without having to lose their Muslim identity. This religion-based social solidarity echoes the notion stating that religion is a reliable basis for a movement organization, in addition to nationalism and ethnicity (Tarrow 2011, 11).

Despite being constitutionally guaranteed, the establishment of an Islamic school in the Netherlands is not always without difficulties and often stimulates public debate. People in favour 
of the presence of an Islamic school are of the opinion that it can 'play an important role in the social integration of the group [Muslims] with maintenance of their own identity' (Shadid and van Koningsveld 2006, 84). Those who are against Islamic schools argue that this kind of schools will 'hinder the integration of the groups [Muslims] concerned into society and thereby diminish their chances of social deployment' [italics, original] (Shadid and van Koningsveld 2006, 84). Many others agree that Islam is 'seen as enforcing rules upon them [Muslims] that inhibit them to take part in society' (Sunier 2005, 323). Muslim immigrants have an Islamic cultural and religious background and Islam is described as a 'potential obstacle' to the immigrants' integration process (Buijs 2009, 428). Some even assume that Islamic schools tend to 'marginalise' or 'radicalise' Muslim youth, although so far, no proof for this has been established (Berglund 2015, 22).

It is worth noting here that the people's perceptions of the presence of Islamic schools 'was and is still strongly divided' (Ter Avest and Rietveld-van Wingerden 2016, 6). In 1992, the majority of the Dutch (57\%) had no objections to Islamic schools. After that, this percentage dropped because many became worried about radical Islam (Ter Avest and Rietveld-van Wingerden 2016, 6). Apparently, Islamic radicalism in some parts of the world, especially since $9 / 11$, has contributed to a change in perception about Islamic schools in the Netherlands. Before this event, Islamic education was never an issue and people assumed that Muslims were merely exercising 'their constitutional right' to establish Islamic schools, just as the Catholics had done in the last century (Verbeek, Entzinger, and Scholten 2015, 223). However, after 9/11 the Dutch people changed their views drastically.

Before 9/11, media coverage on Muslims in the Netherlands tended to focus on their religiosity. However, after $9 / 11$ this focus 'shifted towards the relation between religious fundamentalism and integration' (Sözeri, Kosar-Altinyelken, and Volman 2017, 4). Prime Minister Ruud Lubbers (1982-1994, a Christian Democrat), for example, once encouraged Muslims in the Netherlands to set up their own Islamic pillar. But ten years later, in 2003, Prime Minister Jan-Peter Balkenende (2002-2010, also a Christian Democrat), warned of the danger of Islamic schools and cautioned these schools not to become 'prison[s] of disadvantage' in the country (Verbeek, Entzinger, and Scholten 2015, 223). What happened next was that public officials called for Islamic schools to be closed, because they believed their pupils 'were being indoctrinated into beliefs hostile to other religions, if not to Western culture as a whole' (Merry and Driessen 2016, 856-857).

Evidently, the Dutch community's acceptance of Islamic schools has had its ups and downs. In the beginning (first period) Islamic schools were accepted without suspicion. This cannot be seen without taking domestic and global political conditions into consideration. Domestic political policies allowed immigrant Muslims to practice their beliefs and to educate their children in accordance with their beliefs. The Dutch government worked hard to improve the economic sector and to do this ensured that Muslims would stay in the country to do manual labour (Ter Avest and Rietveld-van Wingerden 2016, 2). Muslim communities' leaders took advantage of this political situation and after lengthy negotiations the authorities finally allowed Muslims to establish the first Islamic school, Al-Ghozali, in Rotterdam in 1987 (Ter Avest and Rietveld-van Wingerden 2016, 6). This resonates with what in social movements is called 'political opportunity' which emphasises resources external to the group. It seems that the leaders of the Muslim community did not hesitate to use their political opportunity and resorted to contentious politics. 'Contentious politics', Tarrow argues, 'emerges when ordinary citizens, sometimes encouraged by leaders, perceive opportunities that lower the costs of collective action, reveal potential allies, show where elites and authorities are most vulnerable, and trigger social networks and collective identities into action around common themes' (Tarrow 2011, 33).

Despite some people's fear that Islamic schools would be used to indoctrinate pupils with fundamentalist interpretations of Islam, we need to consider the fact that, initially, most regular teachers in Islamic schools were 'native Dutch' who were non-Muslims (Maussen and Vermeulen 2015, 90; Dronkers 2016, 16). The schools used non-Muslim teachers because they lacked qualified Muslim teachers. That was one of the challenges of the 43 Islamic primary schools in the 
Netherlands that accommodated the children of Muslim citizens to get education according to their culture and religion (Shadid and van Koningsveld 2006, 81; Maussen and Vermeulen 2015, 90). Another challenge for the survival of Islamic schools was that they had to meet school performance standards. Thus, quality was the measure that decided whether an Islamic school was eligible for subsidising by the State. This brings us to a discussion of the quality of Islamic primary schools in the Netherlands.

\section{Performance of Islamic primary schools}

In general, the performance of Islamic schools in the Netherlands has made some progress. In this section I will analyse both the schools' performance in academic as well as in administrative matters. The most recent information about the performance of Islamic primary schools in the Netherlands can be found, for instance, in the work of Dronkers (2016) and Merry and Driessen (2016).

Academic performance can be seen, among others, from the aggregate of 'the score on a final test at the end of primary school and the teacher's recommendation about the most fitting track' for enrolment to higher tracks (Dronkers 2016, 11). In his study, Dronkers reports that the average score of the national test in the Netherlands is 535 . The minimum score is 501 while the maximum is 550. It is said, 'Islamic schools have on average the lowest score: 531, but that is above the official minimum score' (Dronkers 2016, 11). It must be noted that, 'The Dutch inspectorate applies 527-529 as lower band for schools with more than $60 \%$ low educated parents'. Furthermore, the Dutch inspectorate will categorise a school with a lower score without prospect of improvement as 'a weak or very weak school'. Consequently, such a school loses its students and then its funding as well (Dronkers 2016, 11). Dronkers also found that the final test score average of Islamic schools was very low but still higher than expected, considering the background of the pupils' parents and their low socioeconomic status (Dronkers 2016, 12).

In addition to test scores, the quality of education can also be determined by another aspect such as citizenship. In order to discover the performance of Islamic primary schools in the field of citizenship, I use Merry and Driessen's work. They measured four components of citizenship: 'Knowledge, Reflection, Skills and Attitudes'. They also referred to four central societal tasks, namely 'acting democratically, acting in a socially responsible manner, dealing with conflicts, and dealing with differences' (Merry and Driessen 2016,870 ). With regard to the 'three dimensions (reflection, skill, and attitudes)' it is said that pupils in Islamic schools 'score considerably higher than pupils at comparable schools, and still higher than pupils at the average school' (Merry and Driessen 2016, 871). However, regarding knowledge competence, pupils at Islamic schools have lower scores than those at average schools. These findings are said to challenge opinions that pupils at Islamic schools are 'less likely to cultivate the relevant civic virtues' for Dutch society at large (Merry and Driessen 2016, 871).

To a certain extent, the quality of the schools' performance in administration is poor. Poor management has created 'serious administrative problems in Islamic schools', such as 'misuse of educational money for other purposes, fraud, mismanagement of nominating teachers, serious conflicts within boards, and so forth' (Dronkers 2016, 16). This is so because they lack well-educated and well-connected school board members. As a result, they fail to manage the schools in accordance with the standard of the Inspectorate of Education. The Dutch Inspectorate of Education regularly inspects the quality of the schools' financial administration and when failing standards, a school will be closed. In fact, the Inspectorate of Education closed two Islamic secondary schools in the Netherlands because of 'their failure to run the school properly in accordance with the national norms set out by the inspectorate' (Dronkers 2016, 16).

Islamic schools are seen to lack qualified Muslim teaching staff. Because of this, the schools are 'forced to nominate non-Islamic teachers acceptable to the education inspectorate' (Dronkers 2016, 16). This is not only a problem in Islamic schools but also in Catholic and Protestant schools because of the secularisation in this country. However, 'the need to use non-Muslim teachers by Islamic schools adds additional tensions within these schools, more than in other religious schools' 
(Dronkers 2016, 16). This situation is prevalent in most Islamic schools in the Netherlands. They continue to face many challenges. Firstly, they have to 'struggle to retain their school principals and teachers'. Secondly, as Islamic schools are fully funded by the state they have to struggle finding 'a balance between satisfying the inspectors' and 'creating and sustaining a school climate and ethos' that encourage the school's mission (Merry and Driessen 2016, 872).

The data provided by earlier researchers show that until recently, Islamic schools continue to have the worse achievements compared to public schools in the Netherlands. These poor achievements were caused by, among others, unskilful leaders. It takes a long time to establish Islamic schools in the Netherlands because of the lack of leaders skilled in negotiating with the authorities because they have no experience dealing with the bureaucracy and are unable to speak Dutch (Merry and Driessen 2005, 416).

It should be emphasised here that the provision of Islamic education in the Netherlands involves many parties. It requires a resource mobilization process both at the time of establishment and during daily learning activities, which cannot be done by a single individual or leader. It involves many human resources and requires cooperation in groups and networks. In other words, resource mobilization is a must. This echoes with what Diani calls 'collective action'. Diani, as cited in Tarrow (2011), said that, in general, processes of 'collective action' begin with face-to-face meetings with groups within their social networks and their connecting structures. In the end, however, the decision is in the hands of individuals. In essence, Tarrow argues, it is not 'groupness' itself that induces mobilisation but it is the normative pressure and incentives for solidarity in the network that make the movement emerge and survive (Tarrow 2011, 30).

Notwithstanding having faced many difficulties in the past years, Islamic primary schools are expected to remain strong and optimistic to welcome a brighter future. Working hard and being committed to improve school conditions are keys to success. Indeed, Islamic schools have been said to have made progress and to have improved their academic performance. (Merry and Driessen 2016, 875). One proof of this can be singled out. In 2013, the Dutch Ministry of Education awarded two Islamic primary schools with the title of 'Excellent School'. This was considered a 'remarkable achievement' because only very few schools (32 out of 6800 primary schools in the country) got this recognition (Merry and Driessen 2016, 857).

Islamic primary schools in the Netherlands have two main things to do: take their quality to a higher level and educate their students so that they become 'well-integrated citizens' within Dutch liberal society. Merry and Driessen (2016) notice, 'To help promote this objective, the subject of 'citizenship' was made compulsory in all Dutch schools in 2006'. In order to evade more criticism, Islamic schools were said to actively promote 'integration' and 'good citizenship' in their schools (Merry and Driessen 2016, 873-874). This brings us to a discussion of the efforts made to promote integration and social cohesion in Islamic schools.

\section{Promoting social integration}

First, it should be made clear what is meant by integration. Integration can be defined as 'the participation of groups or individuals in society while retaining and developing their own identity with its essential parts remaining intact' (Elsas 1991, 176). It can be seen as the process during which newcomers or minorities are incorporated into the social structure of the host society (Alba and Nee 1997, 826-874). Contrary to forced assimilation, social integration focuses on the degree to which immigrants adapt to local customs, social relations, and daily practices. It is usually measured by looking at social networks, language usage, and the number of intermarriages (Vigdor 2008). In many cases, education is used as a mechanism for promoting social integration and this is what also happened with Islamic educational institutions in the Netherlands.

Islamic primary schools under the Islamitische Scholen Amsterdam (ISA) and Noor foundations have been singled out as samples in this study. Both have done something in terms of promoting 
the social integration of their pupils into Dutch society. The As-Siddieq school (managed by ISA), for instance, clearly states in its mission:

Onderwijs en opvoeding zijn beide belangrijke componenten binnen onze school. De opvoeding wordt in belangrijke mate bepaald door de waarden en normen vanuit de Islamitische belevingswereld (zoals die zijn opgeschreven in de Koran en overgeleverd in de Soennah) en de waarden die in het kader van actief burgerschap en sociale integratie zijn geformuleerd (https://www.as-siddieq.nl/missie/). [Education and upbringing are both important components within our school. Upbringing is largely determined by the values and norms of the Islamic world experience (as written in the Qur'an and handed down in the Sunnah) and the values formulated in the context of active citizenship and social integration. (Translation, mine)].

The school's mission is to produce pupils who grow up not only according to the norms and values of Islam as derived from the Qur'an and Sunnah, but also based on the values of active citizenship and social integration.

The mission statement also emphasises that the children should be prepared for the world in which they will live, 'Het uiteindelijke leerdoel van het primair onderwijs is, dat het kind zo goed mogelijk wordt voorbereid op het voortgezet onderwijs en de wereld waarin het kind leeft' (www.as-siddieq.nl). [The ultimate objective of primary education is that the child is prepared as well as possible for secondary education and the world in which the child lives. (Translation, mine)]. I think it is a good point for Islamic education to adapt to the local environment, i.e. Dutch society, because it is the place where the children live and will continue to live. This resonates with a notion that the majority of Islamic and Western scholars agree that 'education is a tool to prepare and teach the individual to live according to one's society' (Hussain 2010, 236). This mission statement holds true for all AsSiddieq schools (Al-Jawhara, Al-Yaqoet, and Al-Maes).

Despite the school's statement that it promotes integration, part of the Dutch public remains doubtful. This can be seen, for example, from the following. The Dutch newspaper, Het Parool, reported on a debate contest which was held for elementary school students in Amsterdam in April 2017, in which As-Siddieq participated. During the debate, the pupils discussed statements about multicultural society: whether it is important for children to engage in each other's background. The students proved to be tolerant. As-Siddieq's students also defended the statement that it is important for children to grow up among people of other cultures. During the jury meeting there was a dance performance but when it was about to start, As-Siddieq's students left the hall. The departure of the children itself went smoothly and was not disturbing (Couzy 2017a). The fact that the As-Siddieq students left the hall before the performance of street dancers began was driven by their faith which did not allow them to watch it (Couzy 2017b).

The children's departure was followed by a debate about whether the student's departure was a form of integration, or an example of segregation. Alderman Simone Kukenheim (Education) was expected to investigate what As-Siddieq had done in terms of citizenship and integration (Couzy 2017b). Was it an ultimate sign of integration that As-Siddieq's students participated in the debate and that others took their faith into consideration? According to Geert Driessen, As-Siddieq's participation in the debate competition was positive but walking away when the music was starting was not a nice thing to do, as people live in a society with a lot of music. He considered it a form of segregation (Couzy 2017a). It is worth noting that music and dance may not fit within the fundamentalist interpretation of Islam, but according to the mainstream interpretation of Islam, listening to music is not forbidden or discouraged.

Changes in the political constellation have influenced public perceptions of Muslims and their activities in the Netherlands. The impact of the events of 9/11 on global politics, the murder of rightwing politician, Pim Fortuyn, in 2001 and the murder of Theo van Gogh in 2004 on national Dutch politics helped to exacerbate the perception of the Dutch public towards Islam and Muslims (Ter Avest and Rietveld-van Wingerden 2016, 3). It led to strong criticism and demands to close Islamic schools in the Netherlands. Leaders of the Muslim community were forced to negotiate with powerful opponents in order to defend their interests. This reflects a 'sustaining contention', which is the fourth property in Tarrow's definition of social movements mentioned above. Tarrow said 'it is changes in public political 
opportunities and constraints that create the most important incentives for triggering new phases of contention for people with collective claims' (Tarrow 2011, 11).

Another Islamic primary school, Al-Ihsaan (managed by the Noor foundation) emphasises the right of Muslims to live according to the values and standards of Islam as derived from the Qur'an and the Sunnah because the laws and regulations in the Netherlands allow Muslims to establish Islam-based facilities and thus allow Muslims to express their identity. Likewise, it is important that, 'Muslims make use of all opportunities in the Netherlands so that they can participate optimally. Muslims in the Netherlands have as much responsibility as any other social group in social processes' (Schoolgids Al-Ihsaan 2015-2016, 10). Here, Al-Ihsaan also emphasises the importance of preparing the students to participate optimally in society. This means it does promote integration. All Islamic primary schools under the ISA and Noor foundations explicitly include in their mission statements that their aim is to produce students that fit in and integrate with Dutch society. The future will learn if they are successful in integrating themselves into the host society.

In addition to promoting integration through their schools' missions and by integrating civic education into their curriculum, the ISA and Noor foundations also strengthen the Muslim communities that seek integration. This is evidenced by the rejection of the representatives of Islamic primary schools in the Amsterdam area of the opening of the Islamic high school, Cornelius Haga Lyceum (Smit 2017). The boards of these foundations (ISA and Noor) also advised Muslim parents to avoid that school, which is managed by the Islamic Education Foundation (Stichting Islamitisch Onderwijs/SIO) (De Volkskrant, 6 September 2017; Trouw, 1 August 2017). It was reported that one of the SIO foundation's board members (Abdoe Khoulani) had expressed his sympathy for the Islamic State (IS) on his Facebook account in 2014. Meanwhile, the managing director of the SIO foundation had done nothing to prevent it (Elsevier Weekblad 2017; De Telegraaf, 7 September 2017; Het Parool, 9 September 2017). This raised suspicions that the SIO foundation has connections with Salafist groups (Nederlands Dagblad, 6 September 2017). As Muslims are challenged by integration, Islamic schools can act as 'starting points' in order to create social cohesion and integration into the host society while preserving their students' Muslim identity (Shah 2012, 56).

That the leaders of Islamic educational institutions present their schools' missions to their pupils as promoting social integration can be categorised in a social movement as 'framing'. Framing is 'a process in which social actors, media and members of a society jointly interpret, define and redefine states of affairs' (Tarrow 2011, 144). Indeed, the leaders of Muslim communities need to properly frame the Islamic schools they are operating in the midst of secular Dutch society so that misunderstanding can be avoided.

\section{Conclusion}

Based on the discussion above the following conclusions can be drawn. The Dutch public reacted in two ways to the arrival of Islamic schools in the Netherlands: they were either for or against. In the beginning, the ignorance of the Dutch about the presence of Islamic schools was expected, but over time and after various violent incidents occurred in the Western world that involved Muslim radicals, the Dutch public began to be critical of Islamic schools in their country as they were considered not to contribute to the Muslim's integration process.

In general, Islamic schools in the Netherlands are behind Dutch public schools as far as their accomplishments are concerned. Investigations carried out by the Inspectorate of Education proved that Islamic primary schools had important shortcomings, among them inadequate quality of education and financial mismanagement. However, it seems that Islamic primary schools in the Netherlands have learned from the Inspectorate of Education's negative judgement. As time goes on, they improve themselves to attain a higher level and some are now doing well.

Contrary to the often-heard accusation that Islamic schools obstruct their students' integration process, some have made efforts to promote social integration in accordance with the Primary Education Act in the Netherlands. They have done so among others by including clear statements 
in their school missions confirming their will to be integrated into and become part of Dutch society and by putting civic education in their schools' curriculum. In addition to that, they also strengthen the Muslim community's position in seeking integration.

The findings of the Inspectorate of Education that investigated the Islamic schools' antiintegration tendency in the Netherlands in 2002 that 'almost all Muslim schools played a positive role in creating conditions favourable for the furthering of social cohesion' and that of 2003 stating that education in Muslim schools 'was not contradictory to the basic values of a democratic legal state' and 'to a lesser or greater extent furthered conditions favorable to the integration of the students' (Shadid and van Koningsveld 2006, 86) are confirmed.

The assertion of some politicians who call on Muslim immigrants in the Netherlands to renounce their 'Islamic identity' (Beck 2013, 121) because they are considered unable to adapt to the local culture might be disproportionate. One should take into consideration that identity is not only attributed but also acquired. Moreover, identity as well as values and norms are dynamic and not static. Thus, there is a possibility for Muslims 'to adopt an "Islamic identity" that is completely compatible with the norms and values accepted in the Netherlands' (Beck 2013, 122). Instead of coercing people to give up their religious identity, appreciating religious diversity and tolerance would be 'a better stimulus for social cohesion between groups' (Beck 2013, 122) in society. What some Islamic primary schools championed so far, namely teaching and preparing their students to become good citizens who want to be actively integrated with native Dutch society deserves to be appreciated.

\section{Acknowledgments}

The author would like to thank Prof. Dr. Gerard A. Wiegers from University of Amsterdam (UvA) for granting permission to conduct this research in the UvA (in September 2017).

\section{Funding}

This research project was funded by The Sub-Directorate of Research and Community Service Directorate of Islamic Higher Education Directorate General of Islamic Education Ministry of Religious Affairs of the Republic of Indonesia (2016); The DIPA BOPTN Institute for Research and Community Service (LP2M) Walisongo State Islamic University, Semarang.

\section{Notes on contributor}

Muslih Muslih, obtained his Ph.D. degree in Islamic Studies from Leiden University, The Netherlands in 2006, is a senior lecturer at the Faculty of Education and Teacher Training of Walisongo State Islamic University Semarang, Indonesia. He is now Head of Study Program of Islamic Education Management at Graduate Program at his university.

\section{ORCID}

Muslih Muslih (D) http://orcid.org/0000-0001-8169-155X

\section{References}

Accessed 15 September 2017. https://www.as-siddieq.nl/missie

Accessed 24 March 2019. https://www.statista.com/topics/4905/islam-in-the-netherlands/

Accessed 24 March 2019. http://worldpopulationreview.com/countries/netherlands-population/

Alba, R., and V. Nee. 1997. "Rethinking Assimilation Theory for a New Era of Immigration." International Migration Review 31 (4): 826-874. doi:10.1177/019791839703100403.

Beck, H. L. 2013. "Beyond Living Together in Fragments: Muslims, Religious Diversity and Religious Identity in the Netherlands." Journal of Muslim Minority Affairs 33 (1): 111-127. doi:10.1080/13602004.2013.779069.

Berglund, J. 2015. "Publicly Funded Islamic Education in Europe and the United States (Analysis Paper No. 21, April 2015)." The Brookings Project on U.S. Relations with the Islamic World: Center for Middle East Policy. 
Buijs, F. J. 2009. "Muslims in the Netherlands: Social and Political Developments after 9/11." Journal of Ethnic and Migration Studies 35 (3): 421-438. doi:10.1080/13691830802704590.

Couzy, M. 2017a. "Leerlingen Islamitische School Verlaten Zaal Bij Dansoptreden [Student of Islamic School Leave the Hall at Dance Performance]." Accessed 26 September 2017. https://www.parool.nl/amsterdam/leerlingenislamitische-school-verlaten-zaal-bij-dansoptreden a4487326/

Couzy, M. 2017b. "Voldoet School As-Siddieq Aan Ondergrens Integratie? [Does As-Siddieq School Meet Bottom-Level Integration?]." Accessed 26 September 2017. https://www.parool.nl/amsterdam/voldoet-school-as-siddieq-aanondergrens-integratie a4495078/

De Telegraaf. 2017. "Maskers Af [Masks Off]." September 7. Accessed using Lexis Nexis 16 September 2017.

De Volkskrant. 2017. "Haga Lyceum [Haga Lyceum]." September 6. Accessed using Lexis Nexis 18 September 2017.

Driessen, G., and M. S. Merry. 2006. "Islamic Schools in the Netherlands: Expansion or Marginalization?" Interchange 37 (3): 201-223. doi:10.1007/s10780-006-9001-0.

Driessen, G., and P. Valkenberg. 2000. "Islamic Schools in the Netherlands: Compromising between Identity and Quality?" British Journal of Religious Education 23 (1): 15-26. doi:10.1080/0141620000230103.

Driessen, G. W. J. M., and J. J. Bezemer. 1999. "Background and Achievement Levels of Islamic Schools in the Netherlands: Are the Reservations Justified?" Race Ethnicity and Education 2 (2): 235-256. doi:10.1080/ 1361332990020205.

Dronkers, J. 2016. "Islamic Primary Schools in the Netherlands." Journal of School Choice 10 (1): 6-21. doi:10.1080/ 15582159.2015 .1131508$.

Elsas, C. 1991. "Turkish Islamic Ideals of Education: Their Possible Function for Islamic Identity and Integration in Europe." In The Integration of Islam and Hinduism in Western Europe, edited by W. A. Shadid and P. S. van Koningsveld, 174-186. Kampen: Pharos.

Elsevier Weekblad. 2017. "Salafistische School Trekt Amper Leerlingen [Salafist School Attracts Almost Students]." Accessed 26 September 2017. http://www.elsevierweekblad.nl/nederland/achtergrond/2017/09/salafistische-school -in-amsterdam-trekt-amper-leerlingen-540390/

Het Parool. 2017. "Islambrugklas, Risico of Kans? [Islamic Bridge Class, Risk or Opportunity?]." September 9. Accessed using Lexis Nexis 18 September 2017.

Hussain, A. 2010. "Islamic Education in the West: Theoretical Foundations and Practical Implications." In International Handbook of Inter-Religious Education, edited by K. Engebretson, M. de Souza, G. Durka, and L. Gearon, 235-248. Dordrecht: Springer.

Maussen, M., and F. Vermeulen. 2015. "Liberal Equality and Toleration for Conservative Religious Minorities. Decreasing Opportunities for Religious Schools in the Netherlands?" Comparative Education 51 (1): 87-104. doi:10.1080/03050068.2014.935576.

Merry, M. S. 2005. "Advocacy and Involvement: The Role of Parents in Western Islamic Schools." Religious Education 100 (4): 374-385. doi:10.1080/00344080500308512.

Merry, M. S., and G. Driessen. 2005. "Islamic Schools in Three Western Countries: Policy and Procedure." Comparative Education 41 (4): 411-432. doi:10.1080/03050060500300931.

Merry, M. S., and G. Driessen. 2016. "On the Right Track? Islamic Schools in the Netherlands after an Era of Turmoil." Race Ethnicity and Education 19 (4): 856-879. doi:10.1080/13613324.2014.985586.

Nederlands Dagblad. 2017. "Moslimkoepel Haalt Uit Naar School Salafisten in Amsterdam [Muslim Umbrella Organisation Opposes School of Salafists in Amsterdam]." September 6. Accessed using Lexis Nexis 16 September 2017.

Schoolgids Al-Ihsaan 2015-2016. 2015. "Lelystad: Al-Ihsaan." Accessed 20 September 2017. http://www.noorscholen.nl

Shadid, W. A., and P. S. van Koningsveld. 2006. "Islamic Religious Education in the Netherlands." European Education 38 (2): 76-88. doi:10.2753/EUE1056-4934380206.

Shah, S. 2012. "Muslim Schools in Secular Societies: Persistence or Resistance!" British Journal of Religious Education 34 (1): 51-65. doi:10.1080/01416200.2011.601897.

Smit, P. H. 2017. "Islamitische Basisscholen Verzetten Zich Tegen Nieuwe Islamitische Middelbare School in Amsterdam [Islamic Primary Schools Reject New Islamic Secondary School in Amsterdam]." July 31. Accessed 16 September 2017. https://www.volkskrant.nl/binnenland/islamitische-basisscholen-verzetten-zich-tegen-nieuweislamitische-middelbare-school-in-amsterdam a4508957/

Sözeri, S., H. Kosar-Altinyelken, and M. Volman. 2017. "Mapping Discourses on Mosque Education in the Netherlands: A Content Analysis of the Dutch Press, 2010-2016." Discourse: Studies in the Cultural Politics of Education. doi:10.1080/01596306.2017.1316705.

Sunier, T. 2005. "Constructing Islam: Places of Worship and the Politics of Space in the Netherlands." Journal of Contemporary European Studies 13 (3): 317-334. doi:10.1080/14782800500378409.

Tarrow, S. G. 2011. Power in Movement: Social Movements and Contentious Politics, Revised and Updated Third Edition. Cambridge: Cambridge University Press.

Ter Avest, K. H., and M. Rietveld-van Wingerden. 2016. "Half A Century of Islamic Education in Dutch Schools." British Journal of Religious Education. doi:10.1080/01416200.2015.1128391. 
Trouw. 2017. "Islamitische Basisscholen Ontraden Inschrijving Bij Nieuw Lyceum [Islamic Primary Schools Advises against Enrolment at New Senior High School]." August 1. Accessed using Lexis Nexis 16 September 2017.

Verbeek, S., H. Entzinger, and P. Scholten. 2015. "Research-Policy Dialogues in the Netherlands." In Integrating Immigrants in Europe: Research-Policy Dialogues, edited by Peter Scholten, Han Entzinger, Rinus Penninx, and Stijn Verbeek, 213-231. Dordrecht: Springer.

Van Genugten, S. 2013. "The Netherlands and Islam: In Defence of Liberalism and Progress?" The International Spectator 48 (1): 72-85. doi:10.1080/03932729.2013.758906.

Vigdor, J. L. 2008. Measuring Immigrant Assimilation in the United States. New York, NY: Manhattan Institute. Civic Report No. 53. 